\title{
A note on the effect of low dietary inclusion of extruded wheat on growth performance of post-weaning piglets
}

\author{
F. Vangroenweghe \\ Ghent University, Faculty of Veterinary Medicine, \\ Department of Physiology, Biochemistry and Biometrics \\ Salisburylaan 133, 9820 Merelbeke, Belgium
}

(Received 2 April 2002; accepted 2 August 2002)

\begin{abstract}
The effect of low dietary inclusion of extruded wheat (10\%) on the growth performance of postweaning piglets ( $26 \mathrm{~d}$ ) was studied throughout two experimental periods: PI ( 0 to $14 \mathrm{~d}$ ) and PII ( 5 to $35 \mathrm{~d}$ ). The piglets ( $\mathrm{n}=352$ ) were divided into 2 groups (CONTROL, EXTRUSION), each consisting of 16 units (pens) of 11 piglets/unit. At the end of PlI, weight of piglets was significantly $(\mathrm{P}<0.05)$ higher in the CONTROL compared with the EXTRUSION group. In PII, growth was significantly higher $(\mathrm{P}<0.05)$ in the CONTROL group. Feed consumption did not differ $(\mathrm{P}>0.05)$ between groups throughout the entire study. In PII and throughout the entire study, feed conversion was significantly better $(\mathrm{P}<0.001$ and $\mathrm{P}<0.01$, respectively) in the CONTROL group. Low dietary inclusion of extruded wheat in piglet feeds immediately post-weaning has no beneficial effects on overall piglet performance.
\end{abstract}

KEY WORDS: post-weaning diet, extruded wheat, piglets, cconomic aspects

\section{INTRODUCTION}

Early-weaning systems have induced the market place to search for reasonable solutions to the compromised enzymatic capabilities of young piglets immediately post-weaning (Lindemann et al., 1986; Szabo and Herold, 1995). One of the technologies developed to overcome these problems is extrusion of one or more components in the piglet weaning diet (Harper, 1978; Carter and Leibholz, 1991; Partridge and Gill, 1993; Szabo and Herold, 1995). Inclusion of 15-50\% of flaked components into these diets has been shown to improve weight by $20-40 \%$ during 
the post-weaning period (Szabo and Herold, 1995). However, other studies (Hongtrakul et al., 1998) did not find any improvement in piglet performance during this period. As the costs of extrusion are relatively high (Szabo and Herold, 1995), lower inclusion rates would help to limit diet production costs on condition that piglet performance remains at the same level. The aim of our study was to evaluate growth performance of post-weaning piglets fed a diet with $10 \%$ inclusion of flaked (extruded) wheat.

\section{MATERIAL AND METHODS}

\section{Study location}

The feed trial was performed in a commercial one-site 200-sow unit (Den Bos B.V.B.A., Passendale, Belgium). All sows were F1-hybrids (Large White x French Landrace) and piglets were a crossbred of Fl-hybrid sows and Piétrain boars. All farrowings were organised according to a 3 -week planning system, enabling us to have at least 250 piglets at weaning. Piglets were transferred to a specially equipped post-wcaning unit (ceiling ventilation, $27^{\circ} \mathrm{C}$, ground heating).

Piglets were vaccinated twice against mycoplasmal pneumonia (Suvaxyn ${ }^{\text {(i) }}$ M.Hyo; Fort Dodge Animal Health, Mendota Heights, USA) at $3 \mathrm{~d}$ post-partum and at weaning. From $10 \mathrm{~d}$ post-partum, suckling piglets were fed a starter diet (PorcyStart ${ }^{\top \mathrm{M}}$; Dumoulin Voeders Sanders, Moorslede, Belgium). Overall intake of starter during the suckling period was approximately $180 \mathrm{~g}$ per piglet.

\section{Experimental design}

Piglets were randomly blocked in groups of 11 animals. Each piglet had an equal probability to be assigned to either of the two groups (CONTROL, EXTRUSION). Weight at weaning, number of male castrated piglets and sow parity were equally divided between both groups. All piglets were clinically healthy at weaning.

Piglets were weaned at $26 \mathrm{~d}$ post-partum $(\mathrm{d} \mathrm{O})$ and weighed per block $(\mathrm{n}=11)$ before their transfer into the weaning facilities, using clectronic weighing equipment (Robbe bascules, Torhout, Belgium) with a $100 \mathrm{~g}$ weighing precision.

A total number of 352 piglets were divided into 2 treatment groups (CONTROL, EXTRUSION) and each group consisted of 16 units (pens) of 11 piglets/unit.

The study was divided into 2 experimental periods, period I (PI) from weaning (d O) to $14 \mathrm{~d}$ post-weaning; and period II (PII) from 15 to $35 \mathrm{~d}$ post-weaning. Piglets were weighed at each of these time points.

All events (feeding, weighing, clinical disease, treatment) were registered uniformly on a specific record present in the testing facility. 


\section{Feed formulation}

Wheat was included in both the CONTROL and EXTRUSION diets at a rate of $10 \%$ (Table 1). The wheat component in the post-weaning experimental diet was extruded, using a X-85 Wenger single screw extruder (Wenger, Sabetha, USA). Feed composition of both diets was analysed after preparation (Vitamex, Drongen, Belgium) (Table 2).

TABLE 1

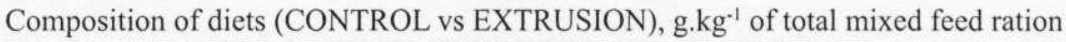

\begin{tabular}{lcc}
\hline & CONTROL & EXTRUSION \\
\hline Fish meal & 50.0 & 50.0 \\
Soyabeans $^{1}$ & 100.0 & 100.0 \\
Piglet post-weaning core substance $^{2}$ & 50.0 & 50.0 \\
Wheat / extruded wheat & 100.0 & 100.0 \\
Maize & 125.0 & 125.0 \\
Barley & 500.0 & 500.0 \\
Dumostart $^{3}$ & 60.0 & 60.0 \\
Fat $^{4}$ & 15.0 & 15.0 \\
\hline
\end{tabular}

' soyabeans (per kg): $2880 \mathrm{kCal} \mathrm{NE}, 33.2 \%$ digestible crude protein, $18.9 \%$ fat, $5.5 \%$ crude fibre and $2.3 \%$ lysine

${ }^{2}$ piglet post-weaning core substance (per kg): 40,000 I.U. Vit. A, 40,000 I.U. Vit. D, 1.000 g Vit. E, $3.2 \mathrm{~g} \mathrm{CuSO}_{4}, 1000 \mathrm{FTU} / \mathrm{kg}$ fytase and anti-oxidant BHT

${ }^{3}$ Dumostart (per kg): $500 \mathrm{~g}$ sour whey powder (per kg; $2338 \mathrm{kCal} \mathrm{NE}, 11.4 \%$ digestible crude protein, $1.0 \%$ fat, $72.0 \%$ lactose) and $500 \mathrm{~g}$ wheat semolina (per kg; $1726 \mathrm{kCal} \mathrm{NE}, 11.6 \%$ digestible crude protein, $4.0 \%$ fat)

${ }^{4}$ fat of animal origin (permitted in Belgium until 07/1999 - Dioxin crisis)

TABLE 2

Chemical composition of diets (CONTROL vs EXTRUSION), g. $\mathrm{kg}^{-1}$ for main components

\begin{tabular}{lcc}
\hline & CONTROL & EXTRUSION \\
\hline Dry matter & 890.0 & 887.0 \\
Crude ash & 56.0 & 51.5 \\
Crude fibre & 43.3 & 43.0 \\
Crude protein & 177.6 & 171.8 \\
Crude fat & 54.2 & 44.6 \\
Sugars & 35.5 & 33.7 \\
Starch & 411.9 & 444.4 \\
Lactose & 23.7 & 20.1 \\
\hline
\end{tabular}


Statistical analysis

A one-sided Student t-test, assuming equal variance, was performed using the following hypothesis:

$$
\begin{aligned}
& \mathrm{H}_{0}: \text { CONTROL } \geq \text { EXTRUSION } \\
& \mathrm{H}_{1}: \text { CONTROL }<\text { EXTRUSION }
\end{aligned}
$$

This hypothesis was tested with a 0.05 significance level. Exact $P$-values are given in the results section.

\section{RESULTS}

\section{Piglet weight and weight gain}

Piglet weight was equal in both groups at the start of the feed trial (Table 3). After the transition period (PI), a slight non-significant difference $(P>0.05)$ was observed between the CONTROL and EXTRUSION group. Final weight was significantly higher $(\mathrm{P}=0.0392)$ in the CONTROL compared with the EXTRUSION group.

TABLE 3

Piglet weight (kg per group) at different $\mathrm{d} 0,14$ and 35 of the feed trial experiment. Data are means $( \pm$ s.e.m) of CONTROL $(n=16)$ and EXTRUSION $(n=16)$ groups

\begin{tabular}{lrr}
\hline & CONTROL & EXTRUSION \\
\hline d O & $71.25 \pm 3.42$ & $71.15 \pm 3.45$ \\
d 14 & $94.82 \pm 3.93$ & $95.15 \pm 3.58$ \\
d 35 & $219.55 \pm 5.55$ & $205.96 \pm 4.98$ \\
\hline
\end{tabular}

During the transition period (PI), weight gain in the CONTROL group was slightly lower as compared with the EXTRUSION group (Table 4). Weight gain during PII was significantly lower $(\mathrm{P}=0.0206)$ in the EXTRUSION group as compared with $\mathrm{P}=0.0417$ ) in the CONTROL group compared with the EXTRUSION group.

TABLE 4

Piglet weight gain (kg per group) during PI, PII and the total experimental period. Data are means $( \pm$ s.e.m) of CONTROL $(n=16)$ and EXTRUSION $(n=16)$ groups

\begin{tabular}{lrr}
\hline & CONTROL & EXTRUSION \\
\hline PI & $23.57 \pm 1.46$ & $24.00 \pm 0.88$ \\
PII & $124.73 \pm 4.47$ & $110.81 \pm 4.75$ \\
TOTAL & $148.30 \pm 5.35$ & $134.81 \pm 5.30$ \\
\hline
\end{tabular}




\section{Feed intake and feed:gain ratio}

No significant differences in feed intake were found in either of the experimental periods (PI, PII and TOTAL) (Table 5).

TABLE 5

Piglet feed intake (kg per group) during PI, PII and the total experimental period. Data are means ( \pm s.e.m) of CONTROL $(n=16)$ and EXTRUSION $(n=16)$ groups

\begin{tabular}{lrr}
\hline & \multicolumn{1}{c}{ CONTROL } & \multicolumn{1}{c}{ EXTRUSION } \\
\hline PI & $34.04 \pm 1.84$ & $34.84 \pm 1.18$ \\
PII & $208.68 \pm 9.15$ & $204.60 \pm 7.39$ \\
TOTAL & $242.71 \pm 9.91$ & $239.44 \pm 7.87$ \\
\hline
\end{tabular}

The feed:gain ratio during the transition period (PI) was equal in both groups (Figure 1). During the subsequent period (PII), feed conversion was significantly better $(\mathrm{P}=0.0001)$ in the CONTROL group $(1.67 \pm 0.03)$, as compared with the EXTRUSION group $(1.87 \pm 0.03)$. Significantly better $(\mathrm{P}=0.0011)$ feed conversion as compared with the experimental group was observed in the CONTROL group throughout the the CONTROL group. The overall piglet weight gain was significantly higher ( $1.79 \pm 0.03$ vs $1.64 \pm 0.03)$.

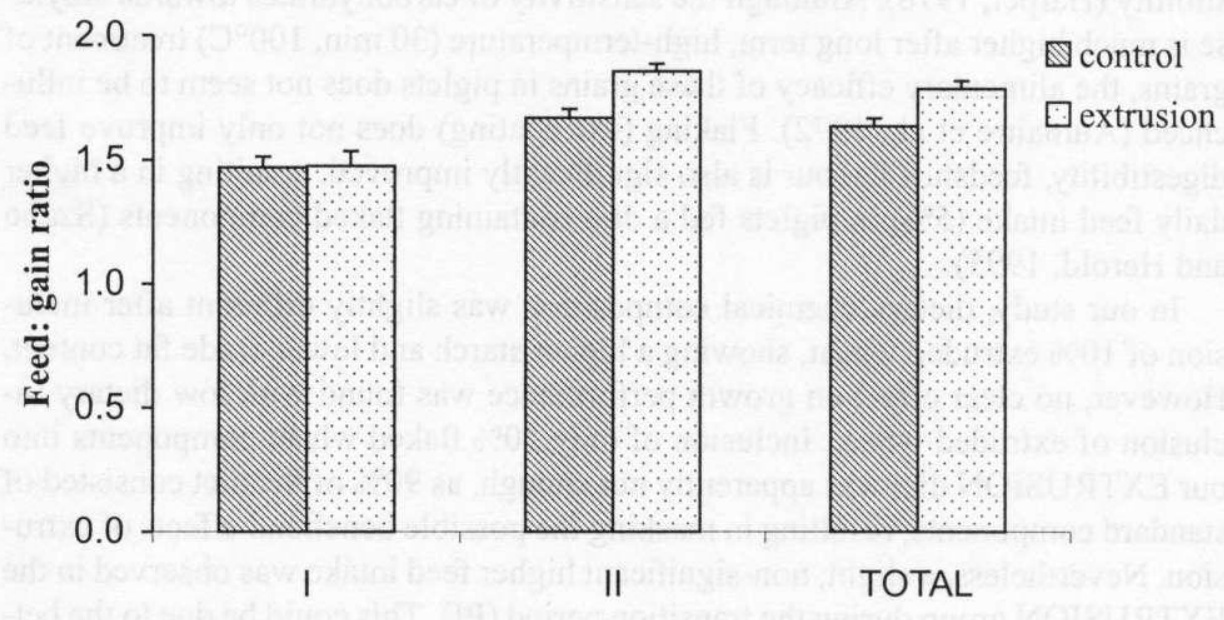

Study period

Figure 1. Feed conversion (feed:gain ratio) throughout the experimental periods: PI, d0 to 14; PII d 15 to 35 ; and total, the entire study duration ( 35 d). Data are means ( \pm s.e.m) of CONTROL $(\mathrm{n}=16)$ and EXTRUSION $(\mathrm{n}=16)$ groups 


\section{DISCUSSION}

Weaning of piglets throughout the EU usually takes place between 3 and 5 weeks of age, with a majority of producers opting for early-weaning (19-25 days). The emphasis on early-weaning systems has favoured the development of relatively high-cost, specialised diets, which almost invariably rely on a significant use of milk products and highly processed raw materials. Considering the efficiency of pig fattening, as well as accustoming animals to forage and roughage as early as possible, it is important to treat feedstuffs so as to make them more readily digestible. However, young animals do not possess a well-developed system of enzymes, ensuring the changeover to these feeds without entailing difficulties. The digestibility of proteins and especially of carbohydrates can be considerably improved during the early post-weaning period. This can be obtained through mechanical or heat treatment or through the addition of enzymes to the prepared diets.

Flaking (extrudating) can be used with success as a feed treatment in piglets to prepare feedstuffs providing improved feed efficiency and extra weight gains during the critical period post-weaning (Szabo and Herold, 1995). Extrusion processing has become an important food process in the manufacture of pasta, readyto-eat cereals, snacks, pet foods and textured vegetable protein. In many of these applications, the extruder is a short high temperature process that minimizes losses in vitamins and amino acids. Major emphasis is placed on the use of extrusion to denature anti-nutritional factors and improvement of protein quality and digestibility (Harper, 1978). Although the sensitivity of carbohydrates towards amylase is much higher after long term, high-termperature $\left(30 \mathrm{~min}, 100^{\circ} \mathrm{C}\right)$ treatment of grains, the alimentary efficacy of these grains in piglets does not seem to be influenced (Aumaître et al., 1972). Flaking (extrudating) does not only improve feed digestibility, fcedstuff flavour is also significantly improved, resulting in a higher daily feed intake $(5 \%)$ in piglets fed a diet containing flaked components (Szabo and Herold, 1995).

In our study, dietary chemical composition was slightly different after inclusion of $10 \%$ extruded wheat, showing a higher starch and lower crude fat content. However, no clear effect on growth performance was found with low dietary inclusion of extruded wheat. Inclusion of only $10 \%$ flaked wheat components into our EXTRUSION diet was apparently not enough, as $90 \%$ of the diet consisted of standard components, resulting in masking the possible beneficial effects of extrusion. Nevertheless, a slight, non-significant higher feed intake was observed in the EXTRUSION group during the transition period (PI). This could be due to the better flavour of diets containing flaked components. However, in the subsequent period (PII) the appetising effect of extrusion disappeared.

Various studies showed that it can be advisable to include flaked ingredients into diets for young pigs, as an addition of only $15 \%$ leads to an excess weight 
gain of $20 \%$ over the weight interval $11-28 \mathrm{~kg}$. Raising flaked components to 35 $50 \%$ even led to $30-40 \%$ excess weight gains in comparison with the control group (Szabo and Herold, 1995). However, as the body weight of the animals increases and their enzyme systems become more developed, the effect of extruded components decreases.

In other studies, growth performance of weanling piglets was not influenced by extrusion processing of their diets (Hongtrakul et al., 1998; Cho et al., 2001). Inclusion of $30 \%$ extruded maize or wheat into diets fed to carly weaned piglets did not influence the average daily growth or average daily feed intake; the feed: gain ratio, in contrast, showed an improvement through this inclusion rate (Cho et al., 2001). In our study, the inclusion rate did not exceed $10 \%$. This can be one of a major reasons for the absence of any effect on feed:gain ratio in the EXTRUSION group.

Nowadays, piglet production is performed on an industrial level and economic aspects seem to have a great impact on the use of flaked ingredients and their associated improvement in piglet performance. Flaking is unfortunately not totally inexpensive, as inclusion rates of 15,35 and $50 \%$ of flaked components into weaning diets result in an increase of total feed costs of 5,11 and $17 \%$, respectively (Szabo and Herold, 1995). Therefore, the cost:return ratio should be evaluated to see whether the improved pig performance more than offsets the higher production costs for these feed components.

In conclusion, limiting the costs of piglet weaning diets through reduced inclusion of extruded components is unfavourable, as it diminishes the known beneficial effects of extrusion.

\section{ACKNOWLEDGEMENTS}

The author would like to acknowledge the excellent technical assistance of André Vangroenweghe and Magda Herman during the entire study period.

\section{REFERENCES}

Aumaître A., Henry Y., Mercier C., Ivorec-Szylit O., Thivend P., 1972. Etude préliminaire de l'influence d'un traîtement hydrothermique sur la valeur alimentaire du blé et du maïs. Ann. Zootech. $21,133-137$

Carter R.R., Leibholz J., 1991. Effects of extrusion of wheat on dry matter and starch digestibility in the young pig. Proceedings of the $3^{\text {rd }}$ Biennial Conference of the Australian Pig Science Association, Albury, NSW, p. 86 
Cho W.T., Kim Y.G., Chae B.J., Kan 1.K., 2001. Effects of feeding extruded corn and wheat grain on growth performance and digestibility of amino acids in early-weaning pigs. Asian-Austr. J. Anim. Sci. 14, 224-230

Harper J.M., 1978. Food extrusion. CRC Crit. Rev. Food Sci. Nutr. 11, 155-215

Hongtrakul K., Goodband R.D., Behnke K.C., Nelssen J.L., Tokach M.D., Bergstrom J.R., Nessmitl W.B., Kim I.H., 1998. The effects of extrusion processing of carbohydrate sources on weanling pig performance. J. Anim. Sci. 76, 3034-3042

Lindeman M.D., Cornelius S.G., el Kandelgy S.M., Moser R.L., Pettigrew J.E., 1986. Effect of age, weaning and diet on digestive enzyme levels in the piglet. J. Anim. Sci, 62, 1298-1307

Partridge G.G., Gill B.P., 1993. New approaches with pig weaner diets. In: P.C. Garnsworth, D.J.A. Cole (Editors). Recent Advances in Animal Nutrition. Nottingham University Press, Loughborough (UK), pp. 221-247

Szabo P.. Herold 1., 1995. Use of extrudate basic materials in feeds for weaned pigs. $46^{\text {th }}$ Annual Mecting of the European Association of Animal Production, Praha (Czecho-Slovakia), pp. 3-10

\section{STRESZCZENIE}

\section{Wplyw dodatku ekstrudowanego ziarna pszenicy do diety na wzrost $i$ rozwój prosiąt po od- sadzeniu}

Badano wpływ $10 \%$ dodatku ckstrudowanej pszenicy do diet na wzrost i rozwój prosiąt odsadzonych w 26 dniu życia, w doświadezeniu podzielonym na 2 okresy: Pl (0-14 dni) i PIl (15-35 dni). 352 prosięta podzielono na 2 grupy - kontrolną i doświadczalną ("ckstrudowaną"), z których każda składała się z. 16 jednostck (kojcy) po 11 prosiąt/kojec. Przy końcu okresu Pll prosięta grupy kontrolnej były istotnie cięższe $(\mathrm{P}<0,05)$ niż doświadczalnej, w wyniku ich wiçkszych przyrostów w drugiin okresie doświadczenia. $W$ ciagu całego doświadezenia prosięta $z$ obydwóch grup pobierały podobną ilość paszy, a wykorzystanie paszy w PII oraz w całym doświadczeniu było lepsze ( $\mathrm{P}<0,001$ oraz $\mathrm{P}<0,01$, odpowiednio) przez prosięta kontroine. Dodatek niedużej ilości ekstrudowanej przenicy do diety dla odsadzonych prosiąt nie miał korzystnego wpływu na ich rozwój. 